\title{
Study on the influencing factors and strategies of sorted collection of urban refuse in China
}

\author{
Yu Fang Bai ${ }^{1,2}$, Jun Chen ${ }^{1,2}$, Dong Biao Wu ${ }^{3}$, Zao Ming Song ${ }^{1,2}$, Chen Gong ${ }^{1,2}$, Zhi Min \\ $\mathrm{Yu}^{1,2}, \mathrm{Ke} \mathrm{Wu} \mathbf{u}^{1,2}$ * \\ ${ }^{1}$ Collaborative Innovation Center for Environmental Pollution Control and Ecological \\ Restoration of Anhui Province, Hefei University, Hefei 230601, P. R. China. \\ ${ }^{2}$ Hefei Institute for Environmental Engineering, Hefei University, Hefei 230601, P. R. China. \\ ${ }^{3}$ Anhui Urban Construction Design \& Research Institute, Hefei 230051, P. R. China. \\ Address: No. 99, Jinxiu Road, Hefei 230601, P. R. China. * Corresponding author e-mail: \\ wuke@hfuu.edu.cn
}

\begin{abstract}
Although the sorted collection of urban refuse in China started later than that in developed countries, it has been sustained 14 years since the implementation of pilot project of waste sorting. However, the waste sorting among cities is still making slow progress and beset with difficulties in China. With a review of the actual situation of waste sorting in China, this article firstly introduced the urban refuse sorted way in China, and then analysed the influencing factors of the sorted collection of urban refuse. At last, we put forward some strategies and suggestions for dealing with the prominent challenges of the sorted collection of urban refuse in China.
\end{abstract}

Keywords: Urban refuse, Sorted collection, Influencing factors, Strategy.

\section{INTRODUCTION}

Waste sorting refers to put the same or similar quality waste together. According to designated time and type, the waste is placed to designated site and then collected by garbage truck, or put into waste recovery system. In developed countries (such as Japan and Germany), waste sorting management has entered a mature stage, while the implementation of waste sorting in China began relatively late and makes slow progress. In 2000, eight cities, such as, Beijing, Shanghai, Guangzhou, Shenzhen, Hangzhou, Nanjing, Xiamen and Guilin, were designated as pilot cities for sorted collection of urban refuse. However, in the past 14 years, the implementation of waste classification in these cities was not going well and still in the process of continuous exploration and research. How to effectively promote this people livelihood project? First and foremost, we should find the real cause of the slow development of the sorted collection of urban refuse. Only after knowing the cause, we can take appropriate measures to promote the stable development of the classification and collection of urban refuse.

\section{THE CLASSIFICATION OF THE URBAN REFUSE IN CHINA}

Different countries have their own ways of classifying urban refuse according to national conditions. For example, Korea classified urban refuse into four kinds: recyclable waste, food waste, large waste and general household waste. In Germany, the urban refuse is divided into four categories: light-weight packing waste (yellow bin), biological waste (brown bin), paper waste (blue bin) and other waste (gray bin).

The urban refuse in China was classified into six sorts by recommended standard: recyclable waste, large-size waste, compostable waste, combustible waste, hazardous waste and other waste. But due to the limitations of waste collection/transportation and terminal disposal facilities, there are hardly any cities can sort urban refuse in more detailed and precise way. Most cities classified urban refuse into merely recyclable waste and other waste. Only a few pilot cities or areas classified urban refuse into recyclable waste, kitchen waste, hazardous waste, other waste and so on. Table 1 showed the present situation of waste 
sorting and disposal in the four pilot cities in China $[1,2,3]$.

TABLE 1

THE GENERAL SITUATION OF URBAN REFUSE SORTING IN PILOT CITIES

\begin{tabular}{|c|c|c|c|c|}
\hline City & Beijing & Shanghai & Guangzhou & Shenzhen \\
\hline $\begin{array}{c}\text { Urban Refuse } \\
\text { Output in } 2014\end{array}$ & $18400 \mathrm{t} / \mathrm{d}$ & $22000 \mathrm{t} / \mathrm{d}$ & $18000 \mathrm{t} / \mathrm{d}$ & $14500 \mathrm{t} / \mathrm{d}$ \\
\hline $\begin{array}{l}\text { Starting Time of } \\
\text { Piloting }\end{array}$ & 1996 & 1995 & 1998 & 1998 \\
\hline Categories & $\begin{array}{l}\cdot \text { Recyclable waste } \\
\cdot \text { Kitchen waste } \\
\cdot \text { Other waste }\end{array}$ & $\begin{array}{l}\cdot \text { Recyclable waste } \\
\cdot \text { Wet waste } \\
\cdot \text { Hazardous waste } \\
\cdot \text { Dry waste }\end{array}$ & $\begin{array}{l}\cdot \text { Recyclable waste } \\
\cdot \text { Kitchen waste } \\
\cdot \text { Hazardous waste } \\
\cdot \text { Other waste }\end{array}$ & $\begin{array}{l}\cdot \text { Recyclable waste } \\
\cdot \text { Hazardous waste } \\
\cdot \text { Other waste }\end{array}$ \\
\hline $\begin{array}{l}\text { Components (and } \\
\text { their proportion) } \\
\text { of Urban Refuse }\end{array}$ & $\begin{array}{l}\text { Kitchen waste:53.61 \%; } \\
\text { Plastics:15.84 \%; } \\
\text { Paper:13.22\%; Glass:1.29 } \\
\text { \%; Dust:1.93\%; } \\
\text { Textiles:1.04 \%; } \\
\text { Metal:1.08\%; Other:11.99 } \\
\%\end{array}$ & $\begin{array}{l}\text { Kitchen waste:31 \%; } \\
\text { Packaging:23 \%; Plastic } \\
\text { bag:18 \%;Paper:12 \%; } \\
\text { Glass:9\%;Harmful and } \\
\text { electronic waste:7 \% }\end{array}$ & $\begin{array}{l}\text { Organic waste:65 \%; } \\
\text { Plastics:8.5 \%; Glass:4 } \\
\text { \%;Paper:2.5 \%; } \\
\text { Other:20 \% }\end{array}$ & $\begin{array}{l}\text { Kitchen waste:47.16 \%; } \\
\text { Paper:8.5 \%; Plastics:10.73 } \\
\text { \%; Glass:2.53 \%; Metal:1.32 } \\
\text { \%; Textiles:3.57 \%; Dust:21 } \\
\text { \%; Other:5.19 \% }\end{array}$ \\
\hline $\begin{array}{c}\text { General Situation } \\
\text { of Urban Refuse } \\
\text { Sorting }\end{array}$ & $\begin{array}{l}\text { There have been more than } \\
3,000 \text { residential area that } \\
\text { implemented urban refuse } \\
\text { sorting management. An } \\
\text { initial urban waste disposal } \\
\text { system was formed, which } \\
\text { involves source separation, } \\
\text { sorted collection, sorted } \\
\text { transportation and sorted } \\
\text { disposal of urban refuse. }\end{array}$ & $\begin{array}{l}\text { At present, urban refuse } \\
\text { sorting covers the } \\
\text { number of residents } \\
\text { about 2,450,000 } \\
\text { households, more than } \\
7,000 \text { units. 2,000 } \\
\text { electronic waste } \\
\text { recycling points were } \\
\text { built. }\end{array}$ & $\begin{array}{l}\text { All } 128 \text { subdistricts and } 36 \\
\text { towns in Guangzhou } \\
\text { started waste sorting } \\
\text { disposal. There are over } \\
30 \% \text { communities having } \\
\text { started substantive waste } \\
\text { sorting out of the } 1400 \\
\text { communities that have } \\
\text { launched the publicity. } \\
\text { Standardized waste } \\
\text { collecting stations cover } \\
\text { more than } 90 \% \\
\text { communities. }\end{array}$ & $\begin{array}{l}\text { In 2013, there are } 527 \text { units } \\
\text { (communities) participated in } \\
\text { the "Construction of Model } \\
\text { Unit in Waste Reduction and } \\
\text { Sorting”. } 261 \text { residential } \\
\text { communities and more than } \\
230,000 \text { households took } \\
\text { part. }\end{array}$ \\
\hline $\begin{array}{c}\text { Terminal Disposal } \\
\text { Mode and } \\
\text { Disposal } \\
\text { Capability }\end{array}$ & $\begin{array}{l}\text { At present, there are } 37 \\
\text { urban refuse disposal } \\
\text { facilities } \\
\text { ( } 9 \text { transfer stations, } 4 \\
\text { incineration plants, } 16 \\
\text { sanitary landfills, } 6 \\
\text { composting plants, } 2 \\
\text { kitchen waste treatment } \\
\text { plants), and the disposal } \\
\text { capacity is } 22000 \mathrm{t} / \mathrm{d} \text {. }\end{array}$ & $\begin{array}{l}\text { At present, there are } 6 \\
\text { waste disposal facilities } \\
\text { ( } 3 \text { incineration plants, } 2 \\
\text { sanitary landfills,1 } \\
\text { resource utilization } \\
\text { center), and the disposal } \\
\text { capacity is } 18042 \mathrm{t} / \mathrm{d} \text {. }\end{array}$ & $\begin{array}{l}\text { At present, there are } 4 \\
\text { waste disposal facilities } \\
\text { ( } 2 \text { incineration plants, } 2 \\
\text { sanitary landfills), and the } \\
\text { disposal capacity is } \\
\text { 14000t/d. }\end{array}$ & $\begin{array}{l}\text { At present, there are } 10 \text { waste } \\
\text { disposal facilities } \\
\text { ( } 7 \text { incineration plants, } 3 \\
\text { sanitary landfills), and the } \\
\text { disposal capacity is } 11000 t / d \text {. }\end{array}$ \\
\hline $\begin{array}{c}\text { Rate of } \\
\text { NonHazardous } \\
\text { Disposal }\end{array}$ & $99.1 \%$ & $91.4 \%$ & $92 \%$ & $98.3 \%$ \\
\hline
\end{tabular}

III THE INFLUENCING FACTORS OF URBAN REFUSE SORTING IN CHINA

Laws and regulations on urban refuse sorting are imperfect, and implement difficulty

There have been enacted many laws and regulations on environmental protection, but the relevant laws, regulations and detailed rules for the sorting and classification of urban refuse, have still been under research or in pilot phase and without any substantial breakthrough. If there are no relevant laws and regulations as the legal basis and supporting for the implementation of waster sorting, it cannot be enforced steadily and successfully.

Furthermore, sorting waste was without a unified standard and differed in relevant policies and local regulations of different regions. In such a large country with strong population mobility as China, the people livelihood project of waste sorting would not be 
promoted well if there is no a unified waste classification standard $[2,4]$.

No system was builted for sorted collection/transportation and disposal of urban refuse

At present, the facilities for separating urban refuse in China are far from being perfect. There is no clear distinction of waste source specified in dustbins or trash cans in most regions. In some regions, although source-separating dustbins and trash cans have been equipped in many places, e.g., both sides of the roads, residential quarters, enterprise, and public institutions, only two slots of recyclable waste and other waste are given on the dustbins. Which cannot meet the requirement of further sorting of waste. The current urban refuse compression and transportation machinery equipment is hardly with the function of classified compression and transportation. So the two separated kinds (recyclable waste and other waste was separated in the collection) would mix together again in transportation. Sorted disposal is the ultimate purpose of sorted collection and transportation. But in most regions of China, the urban refuse was final disposaled by traditional ways, such as sanitary landfill, composting or incineration for electricity generation. There are only a few waste sorting and recycling factories and comprehensive utilization treatment plants. Such facts will eventually lead to meaningless waste classification. There are close correlations the source separation and sorted collection of urban refuse, sorted transportation, and the final sorted disposal. No system was built for sorted collection and transportation and disposal of urban refuse is one of the main causes of the difficulties in waste sorting $[4,5,6]$.

\section{Unclear management responsibility and insufficient} fund of urban refuse sorting

Waste management in China involves a number of sections at current stage. Waste of residential quarters was collected by environmental sanitation section of the sub-district. Waste of enterprise and public institution was collected and disposed by their own. Waste in the dustbins on the roads was collected by local Urban Management Bureau. Hazardous waste and expired drugs was dealted with by environmental protection administration and Food and Drug Administration, respectively. The management results in a chaotic situation of waste dispose. Waste sorting would not become effective and successful naturally. In addition, at present in China, the main emphasis of urban waste management is on terminal disposal and with less attention to the initial sorting of waste sources and sorted transportation. Moreover, the charge system for urban waste management has not been carried out in most cities in China, it is still aomost depending on fiscal investment, which incurs a financial overload and less money put into the sorting of waste, thus affects the input and update of the facilities used for sorting, transporting and disposing urban refuse $[2,6,7]$.
Citizens with low environmental awareness, insufficient knowledge of waste sorting, low degree of participation

In China, as the urbanization accelerates, population mobility between urban and rural areas and among regions also becomes faster, which makes a considerable difference of environmental awareness among citizens. Some people with low environmental awareness discards trash at will, not to mention sorting the rubbish. Citizens with a relatively high environmental awareness would just discard rubbish into dustbins or trash cans without any distinguishing. There are even some people mix hazardous waste as waste battery and modulator tube with general domestic refuse. The publicity of waste classification by the relevant departments of the government or public organization is also insufficient, so that the citizens merely know relevant concepts of waste sorting but lack of the knowledge of urban refuse classification method. Naturally, waste sorting has not become a joint action $[8,9,10]$.

\section{STRATEGIES FOR THE SORTED COLLECTION OF URBAN REFUSE IN CHINA}

To establish sound and easy-facilitate laws, regulations and policies on urban refuse sorting

Waste sorting needs to be guided and normalized by a series of laws, regulations and policies. What can be done can be summarized as follows: formulate mandatory laws and relevant supporting regulations on the sorting of urban refuse, develop sound management methods for the sorting of urban refuse, supervision and examining system of sub-district office and communities for the sorting, to introduce relevant policies paying equal attention to sorting, transportation and disposal of urban refuse, to establish rewards and penalties system concerning the sorting of urban refuse and urban refuse charge system, to elaborate the classification standards and detailed rules for hazardous waste. Through these laws, regulations and policies, a scientific, implement and nationwide-applicable legal system on the sorted collection of urban refuse can be constructed. And detailed enforcement rules for waste sorting should be elaborated gradually, and unified classification standards and methods should be specified. Such unified laws and regulations are easy to advocate and convenient for administration. So no matter where you are in China, you only need to know one unified classification policy [11].

To strengthen the construction and accomplish of the facilities for sorting, transporting and disposing urban refuse

The purpose of waste sorting is sorted transportation, and the purpose of sorted transportation is sorted disposal. So the ultimate goal of waste sorting is sorted disposal. Currently, the sorting facilities in 
most regions of China merely make the distinction between recyclable waste and other waste, while there is few specified subdivision of waste compression and transportation facilities. The terminal disposal is mainly conducted in three ways, such as sanitary landfill, composting and incineration for electricity generation. Therefore, it is necessary to update the present facilities used for sorting the waste, and also the technological research and development of facilities. So the new facilities can be put into application as soon as possible. Additionally, the sorted disposal of urban refuse needs government support. With a lower requirement for access, entrepreneurs would take an active part in sorted collection and disposal of waste, making the sorting and disposal of urban refuse reach a large scale, thus gradually improve the virtuous circle of the sorted collection and disposal of urban waste [5]. To make a sound management and supervision system of urban waste, and to promote the waste charge system

Concerning the chaotic situation of urban waste sorting and management, it can solve this problem by choosing a department which has more power and influence, a high level of administration, and stable financial source to be in charge of the urban refuse sorting. Which can unified dispatch and manage other different departments. Concerning the emphasis on terminal disposal, administrative department ought to ensure the management balance among all the sorted collection, sorted transportation and sorted disposal, rather than a highlight on a particular part. Less attention to any part(s) would affect the whole management system. Besides, the waste disposal charge system should be carried out, which can ease the fiscal burden of urban refuse disposal, and also enhance the participation of citizens into the sorted collection of urban refuse [11].

To enhance the publicity and advocacy of urban refuse sorting, and to gradually raise citizens' environmental awareness

Firstly, publicity of waste sorting requires a combination of school education and social education. Knowledge of waste sorting shall be given to students of different levels, from primary school to college, and the relevant knowledge reserve would be increased gradually. So citizens have good habit of waste sorting from early age. Meanwhile, the neighborhood committee publicize the knowledge of waste sorting in the community according to different ages and education levels. Secondly, the publicity function of news media should be highlighted. Print media, radio and television, and new media can all be employed to publicize the knowledge of environmental protection and waste sorting. A long-term publicity will exert a subtle influence on people, and they can naturally understand waste sorting knowledge. Last but not least, it is not be ignored the NGOs and environmental protection volunteers, who are more familiar with relevant waste sorting knowledge and ways of publicity.
The governmental departments might print brochures or pamphlets on waste sorting and offer to these organizations, to guide the residents into the waste sorting work more actively $[3,12,13]$.

\section{CONCLUSIONS}

The sorted collection of urban refuse is the inevitable requirement and prerequisite of the "minimization" "harmlessness" and "recycling" process of waste. Which is also the irresistible trend of urban refuse disposal. In order to well realize the sorting of urban refuse, it not only need to establish sound laws, regulations and policies on waste sorting, but also to insist a long-term extensive publicity through various channels, and to consolidate the management and supervision system of urban refuse sorting. More importantly, the route by which waste goes from source separation to final disposal should be made unimpeded. It is necessary to establish a virtuous cycle of sorted collection, sorted transportation and sorted disposal of urban refuse system, so that the goal of transforming sorted urban refuse into resources can be achieved.

\section{ACKNOWLEDGMENTS}

This research was supported by the project of the development subject leader in HeFei university (2014dtr02), and the project of key discipline in HeFei university(2014xk01)

\section{REFERENCES}

[1] Liu M. Garbage sorting experience in developed countries and its enlightenment to China. Journal of Southwest University for Nationalities (Humanities and Social Science) 32. 2011, pp. 98-101. (In Chinese)

[2] Chen Y.R., Li X. Pilot city status analysis of MSW classification and management. Journal Industrial Safety and Environmental Protection 2. 2014, pp. 93-95. (In Chinese)

[3] Luo Y.S. Research on the implementation effect, problems and countermeasures of MSW classification policy in Guangzhou. Journal of Suzhou Education Institute 1. 2014, pp. 14-17. (In Chinese)

[4] Xie H. City garbage classification and resource utilization. Journal of Green Science and Technology 2. 2014, pp. 213-214. (In Chinese)

[5] Zhong M., Ma Y.L., Yin A.J. Suggestions about setting up the primary garbage sorting station in the residential area, Journal Inner Mongolia Environmental Sciences 10. 2013, pp.153-155.

[6] Zhang Hong, Discussion on the MSW classification and treatment. Journal Science and Technology Innovation Herald 23. 2013,pp.110-111. (In Chinese)

[7] Xiong H.Y., Wan Y.F, Research of the classification, collection, transportation and processing for Wuhan municipal solid waste. Journal Industrial Safety and Environmental Protection 3. 2014, pp. 80-83. (In Chinese)

[8] Ma X.J. On-and-off "garbage sorting". Journal the people's Public Security 1. 2014, pp. 16-18. (In Chinese)

[9] Wang X.H., Ruan X., Xing F.F. The bottleneck and countermeasures about the source separation of household garbage in Shanghai. Journal Recycling Research 6. 2013, pp. 24-27. (In Chinese)

[10] Li J.Y. Optimizing waste classification treatment and building green low carbon capital. Journal Public Communication of Science \& Technology 16. 2013, pp. 104-124. (In Chinese) 
Yu Fang Bai, et al./ Environment. Technology. Resources, (2015), Volume II, 51-55

[11] Liu Y.F. Study on the problem of MSW classification and recycling in China. Journal Science Technology and Enterprise 9. 2013, pp. 141. (In Chinese)

[12] He L.H. The significance and countermeasure of MSW classification and collection in China. Journal Jiangxi Chemical Industry 4. 2013, pp. 326-328. (In Chinese)
[13] Wang S. China's garbage sorting governance in urban communities: connotation, problems and thoughts. Journal of Beijing Polytechnic College 1. 2014, pp.112-115. (In Chinese). 